\title{
$\mathcal{A}_{\text {нализ распространенности и заболеваемости }}$ дерматозами у работников алтайского региона Западно-Сибирской железной дороги
}

Карпова О. А.

Отделенческая клиническая больница на станции Барнаул ОАО «Российские железные дороги» 656038, Российская Федерация, г. Барнаул, ул. Молодежная, д. 20

В статье представлены результаты сравнительного анализа распространенности и заболеваемости болезнями кожи и подкожной клетчатки у работников железнодорожного транспорта алтайского региона, Западно-Сибирской железной дороги, ОАО «РЖД» и территориального населения Сибирского федерального округа и Российской Федерации.

Ключевые слова: болезни кожи и подкожной клетчатки, работники железнодорожного транспорта

Конфрликт интересов: автор заявляет об отсутствии потенциального конфрликта интересов, требующего раскрытия в данной статье.

Для цитирования: Карпова О. А. Анализ распространенности и заболеваемости дерматозами у работников алтайского региона Западно-Сибирской железной дороги. Вестник дерматологии и венерологии. 2018;94(3):13-19. https://doi.org/10.25208/0042-4609-2018-94-3-13-19 


\section{Analysis of the prevalence and incidence of the dermatosis in workers of the Altay region, of the West-Siberian Railways}

Ol'ga A. Karpova

Departmental Hospital at the Station of Barnaul JSC "Russian Railways"

Molodedjnaja str., 20, Barnaul, 656038, Russian Federation

In article presents the results a comparative analysis of the prevalence and incidence of the skin and subcutaneous tissue diseases in the railway transport workers of the Altay region, of the West-Siberian Railways, of JSC Russian Railways and the local population of the Siberian Federal district, and the Russian Federation.

Keywords: skin and subcutaneous tissue diseases, railway transport workers

Conflict of interest: the author states that there is no potential conflict of interest requiring disclosure in this article.

For citation: Karpova O. A. Analysis of the prevalence and incidence of the dermatosis in workers of the Altay region, of the West-Siberian Railways. Vestnik Dermatologii i Venerologii. 2018;94(3):13-19. https://doi.org/10.25208/00424609-2018-94-3-13-19 
Цель исследования - провести сравнительный анализ общей и первичной заболеваемости по классу болезни кожи и подкожной клетчатки у прикрепленного к НУЗ ОКБ на станции Барнаул населения, работников Алтайского региона Западно-Сибирской железной дороги ОАО «РЖД» и территориального населения СФО и РФ.

Материалы и методы. Для ретроспективного, сравнительного статистического анализа были использованы данные базы Росстата URL: www.gks.ru, ФГБУЗ “Сибирский окружной медицинский центр» ФМБА России http://www.somc-nsk.ru., статистических отчетов Центральной дирекции здравоохранения - филиала ОАО «РЖД», статистические отчетные фрормы № 12 Западно-Сибирской дирекции здравоохранения - филиала ОАО «РЖД», НУЗ ОКБ на станции Барнаул [2-4].

Статистическая обработка результатов проводилась с использованием пакета программ Statistica 10.0. Нормальность распределения количественных признаков в выборочных совокупностях определялась при помощи W-теста Шапиро - Уилка. Описательная статистика приводилась в тексте виде среднего значения и стандартного отклонения $(M \pm S D)$. Для сравнения групп с распределением признака, отличного от нормального, применяли непараметрический метод: U-тест Манна Уитни. Различия считали статистически значимыми при $p<0,05$.

\section{Результаты исследования и их обсуждение}

Пути Алтайского региона Западно-Сибирской железной дороги филиала ОАО «РЖД» (ЗСЖД) проходят по территории Алтайского края и части Новосибирской области. В состав отделения входят четыре узла: Барнаульский, Алтайский, Рубцовский и Кулундинский. Большая часть работников отделения прикреплена на медицинское обслуживание к негосударственному учреждению здравоохранения «Отделенческая клиническая больница на станции Барнаул» ОАО «РЖД» (НУЗ ОКБ ст. Барнаул). Больница оказывает медицинскую помощь только взрослому населению.

Общая численность населения, обслуживаемого НУЗ ОКБ на ст. Барнаул в 2016 г., 21727 человек. Из них работники ОАО «РЖД» составили 7298 человек 34,9 \% (2015 г. - 33,3 \%; 2014 г. - 33,9 \%), пенсионеры железнодорожного транспорта - $26 \%$ (2015, 2014 гг. $23 \%$, территориальное население - $39 \%$. В структуре прикрепленного контингента удельный вес работников компании по сети дорог занимает 29,2 \%, по ЗападноСибирской железной дороге - 28,6 \%.

Количество лиц, обеспечивающих безопасность движения поездов в 2016 г., по ОКБ ст. Барнаул, составило 4298 человек (2015 г. - 4226 человек; 2014 г. 4383 человека).

В 2016 г. 8648 (95,3%) работников Алтайского региона ЗСЖД работали во вредных и опасных условиях труда (2015 г. - 96,2 \%; 2014 г. - 96,3\%).

Лица, работающие на железнодорожном транспорте, подвергаются влиянию различных вредных и опасных производственных фракторов. В среднем на каждого работника их воздействует около восьми. По последним гигиеническим критериям большинство железнодорожных профессий относится к классам 3.1-3.4 (с высоким риском развития профзаболеваний).

Из предприятий наиболее неблагоприятные условия труда имеют локомотивные депо и дистанции пути.

Такие вредные для здоровья условия труда сказались на повышенной заболеваемости дерматозами работников Алтайского региона (табл. 1).

В 2016 г. среди работников Алтайского отделения ЗСЖД всего было диагностировано 572 заболевания кожи и подкожной клетчатки, что соответствует интенсивному показателю 46,9 на 1000 работающих; в 2015 г. - 591 случай, в 2014 г. - 608 случаев. Общая заболеваемость по классу «Болезни кожи и подкожной клетчатки» по алтайскому региону с 2011 по 2016 г. снизилась на 31,6 \%. Наибольшее значение показателя 69,7 на 1000 работающих зарегистрировано в 2012 г., а наименьшее - 47,7 на 1000 работающих — к концу периода. В среднем общая дерматологическая заболеваемость на Алтайском отделении за шестилетний период составила 55,4 \pm 9,2 на 1000 работающих. Prevalence заболеваниями кожи и подкожной клетчатки у работников основной деятельности в 1,3 раза выше, чем у всего прикрепленного к НУЗ ОКБ ст. Барнаул населения (43,4 \pm 14,1 на 1000 взрослого населения). Достоверных различий общей заболеваемости работников железнодорожного транспорта алтайского региона с дорожными $(p=0,179654)$ и сетевыми $(p=0,393939)$ показателями выявлено не было. Это можно расценить как влияние условий труда на организм работников железнодорожного транспорта и распространенность болезней кожи и подкожной клетчатки у работников

Таблица 1. Общая заболеваемость по классу «Болезни кожи и подкожной клетчатки», 2011-2016 гг. (на 1000 взрослых) Table 1. General incidence of skin and subcutaneous tissue diseases in 2011-2016 (per 1,000 adults)

\begin{tabular}{|c|c|c|c|c|c|c|c|c|}
\hline \multicolumn{2}{|c|}{ Население / год } & 2011 & 2012 & 2013 & 2014 & 2015 & 2016 & $\mathrm{M} \pm \mathrm{SD}$ \\
\hline \multirow{2}{*}{ Алтайский регион } & ${ }^{1}$ (на 1000 раб.) & 59,8 & 69,7 & 60,0 & 48,1 & 48,1 & 46,9 & $55,4 \pm 9,2$ \\
\hline & 2 (на 1000 взр.) & 56,5 & 57,2 & 47,7 & 46,7 & 25,9 & 26,3 & $43,4 \pm 14,1$ \\
\hline \multirow{2}{*}{ ЗСЖД } & ${ }^{3}$ (на 1000 раб.) & 55,0 & 51,6 & 49,3 & 45,1 & 39,9 & 40,3 & $46,9 \pm 6,2$ \\
\hline & ${ }^{4}$ (на 1000 взр.) & 41,2 & 40,1 & 32,1 & 31,1 & 30,7 & 31,6 & $35,0 \pm 5,2$ \\
\hline \multirow{2}{*}{ ОАО «РЖД» } & ${ }^{5}$ (на 1000 раб.) & 64,1 & 61,5 & 59,1 & 61,3 & 57,3 & 54,2 & $59,6 \pm 2,5$ \\
\hline & ${ }^{6}$ (на 1000 взр.) & 42,1 & 42,4 & 45,0 & 41,9 & 40,3 & 39,3 & $41,8 \pm 2,0$ \\
\hline \multicolumn{2}{|c|}{${ }^{7}$ СФО (на 1000 взр.) } & 47,2 & 48,4 & 48,5 & 50,6 & 45,6 & 45,1 & $48,1 \pm 1,8$ \\
\hline \multicolumn{2}{|c|}{${ }^{8}$ РФ (на 1000 взр.) } & 50,7 & 51,1 & 50,9 & 51,0 & 49,7 & 49,0 & $50,7 \pm 0,6$ \\
\hline
\end{tabular}

Примечание / Note: $p_{1-2}=0,093074 ; p_{1-3}=0,179654 ; p_{1-4}=0,002165 ; p_{1-5}=0,393939 ; p_{1-6}=0,002165 ; p_{1-7}=0,240260 ; p_{1-8}=1,000000 ; p_{2-4}=0,393939 ; p_{2-6}=0,393939 ; p_{2-7}=$ 0,$937229 ; p_{28}=0,393939$ 
отрасли. О том, что условия труда влияют на накопленную заболеваемость дерматозами, свидетельствует и достоверно более высокая $(p=0,002165)$ по сравнению с распространенностью патологии кожи у работников отделения, чем у общего взрослого населения, прикрепленного к НУЗ ЗСЖД (35,0 \pm 5,2 на 1000 взрослого населения) и ОАО «РЖД» $(41,8 \pm 2,0$ на 1000 взрослого населения). Общая дерматологическая заболеваемость у работников алтайского региона выше дорожных 46,9 × 6,2 на 1000 работающих, но ниже сетевых показателей $-59,6 \pm 2,5$ на 1000 работающих. В ходе исследования было доказано, что распространенность болезней кожи у работников основной деятельности Алтайского отделения выше, чем у территориального населения СФО $(p=0,24026)$ и РФ $(p=1,0)$, но при этом достоверности различия признаков получено не было [1].

В структуре prevalence взрослого населения Алтайского региона ЗСЖД в 2016 г. болезни кожи и подкожной клетчатки составили 2,2 \%, по дороге - 3,2 \%. Внутри самого класса преобладают аллегодерматозы39,9 \% за счет контактного дерматита - 36,2 \%. Второе место по распространенности занимает псориаз $18,5 \%$, третье - атопический дерматит - 3,7 \%.

Общая заболеваемость атопическим дерматитом у работников Алтайского региона в среднем с 2005 по 2016 гг. составила 1,1 \pm 0,1 на 1000 взрослого населения (табл. 2). Это достоверно ниже распространенности атопического дерматита, чем у работников ЗСЖД $(p=0,015606)$ и территориального населения СФО $(p=0,000001)$ и РФ $(p=0,000003)$.

В 2016 г. по Алтайскому региону ЗСЖД всего было выявлено 207 контактных дерматитов (табл. 3). Это наименьший за 12 лет показатель. С 2005 г. регресс контактного дерматита составил 36,7 \% относительно наивысшего уровня (21,5 на 1000 работающих 2010 г.). Но, несмотря на это, уровень распространенности контактного дерматита по отделению достоверно выше, чем на дороге в целом $(p=0,000401)$ и у территориального населения $(p=0,000401)$.

Достоверно самые высокие показатели распространенности псориаза среди анализируемых групп - 5,6 \pm 0,9 на 1000 работающих - зарегистрированы на Алтайском отделении дороги по сравнению со среднедорожными 3,9 \pm 0,6 на 1000 работающих $(p=0,001243)$ и территориальными показателями СФО 2,3 \pm 0,2 на 1000 соответствующего населения $(p=0,000666)$ и РФ 3,0 \pm 0,9 на 1000 взрослого населения $(p=0,000311)$ (табл. 4$)$.

С 2009 по 2016 г. произошел регресс распространенности псориаза по алтайскому региону на 31,4 \%.

Первичная заболеваемость дерматозами по алтайскому региону ЗСЖД в 2016 г. в структуре общей составила 71,2 \%. Доминирующими заболеваниями в структуре incidence по классу болезни кожи и подкожной клетчатки у населения Алтайского отделения ЗСЖД в 2016 г. являлись контактный дерматит - 47,4 \% и псориаз - 2,2 \% (табл. 5).

В 2016 г. у работников Алтайского отделения ЗСЖД было выявлено 407 новых заболеваний кожи и подкожной клетчатки; в 2015 г. - 417 случаев, в 2014 г. 425 случаев (табл. 5). Показатель 2016 г. соответствует заболеваемости 39,9 на 1000 работающих. Первичная дерматологическая заболеваемость у работников отделения составляет 8,3 \% в общей структуре. За период

Таблица 2. Распространенность атопического дерматита, 2005-2016 гг. (на 1000 взрослого населения)

Table 2. Prevalence of atopic dermatitis in 2005-2016 (per 1,000 adult population)

\begin{tabular}{|c|c|c|c|c|c|c|c|c|c|c|c|c|c|c|}
\hline Регион/год & & 2005 & 2006 & 2007 & 2008 & 2009 & 2010 & 2011 & 2012 & 2013 & 2014 & 2015 & 2016 & $M \pm S D$ \\
\hline \multirow{2}{*}{${ }^{1}$ Алтай } & абс. & 19 & 22 & 21 & 19 & 19 & 17 & 19 & 20 & 19 & 28 & 26 & 21 & \\
\hline & $\%$ & 1,3 & 0,97 & 0,97 & 0,96 & 1,07 & 1,05 & 1,3 & 1,3 & 1,3 & 1,2 & 1,1 & 0,97 & $1,1 \pm 0,1$ \\
\hline \multirow{2}{*}{ зСЖД } & абс. & 761 & 206 & 700 & 721 & 390 & 555 & 521 & 557 & 404 & 261 & 262 & & \\
\hline & $\%$ & 2,2 & 0,62 & 2,2 & 2,6 & 1,2 & 2,2 & 2,0 & 2,2 & 1,6 & 1,1 & 1,1 & & $1,7 \pm 0,6$ \\
\hline${ }^{3} \mathrm{C} Ф 0, \%$ & & 1,9 & 1,9 & 1,9 & 1,9 & 1,9 & 1,8 & 1,7 & 1,7 & 1,6 & 1,6 & 2,5 & & $1,9 \pm 0,3$ \\
\hline${ }^{4} \mathrm{P} \Phi, \%$ & & 1,9 & 2,0 & 2,2 & 2,5 & 2,5 & 2,1 & 2,1 & 1,9 & 2,0 & 2,1 & & & $2,1 \pm 0,2$ \\
\hline
\end{tabular}

Примечание / Note: $p_{1-2}=0,015606 ; p_{1-3}=0,000001 ; p_{1-4}=0,000003 ; p_{2-3}=0,000001 ; p_{2-4}=0,002761$

Таблица 3. Распространенность контактного дерматита, 2005-2016 гг. (на 1000 взрослого населения)

Table 3. Prevalence of contact dermatitis in 2005-2016 (per 1,000 adult population)

\begin{tabular}{|c|c|c|c|c|c|c|c|c|c|c|c|c|c|}
\hline \multicolumn{2}{|c|}{ Регион / год } & 2005 & 2006 & 2007 & 2008 & 2009 & 2010 & 2011 & 2012 & 2013 & 2014 & 2015 & 2016 \\
\hline \multirow{2}{*}{ Алтай } & абс. & 220 & 359 & 460 & 477 & 364 & 350 & 269 & 259 & 220 & 213 & 215 & 207 \\
\hline & $\%$ & 15,0 & 15,8 & 21,2 & 24,0 & 20,5 & 21,5 & 17,7 & 17,8 & 15,0 & 9,4 & 9,4 & 9,5 \\
\hline \multirow{2}{*}{ ЗСЖД } & абс. & 3363 & 3374 & 3753 & 3761 & 2443 & 2295 & 2048 & 2123 & 1735 & 1547 & 2017 & \\
\hline & $\%$ & 9,6 & 10,2 & 12,1 & 13,5 & 9,1 & 8,7 & 7,6 & 8,2 & 7,1 & 6,2 & 8,6 & \\
\hline \multicolumn{2}{|c|}{${ }^{3} \mathrm{CФ0,} \mathrm{\% о}$} & 8,4 & 8,7 & 9,3 & 9,1 & 9,2 & 9,8 & 9,3 & 10,2 & 10,2 & 10,5 & 8,6 & \\
\hline \multicolumn{2}{|c|}{${ }^{4} \mathrm{P} \Phi, \%$} & 9,1 & 9,5 & 9,7 & 9,7 & 10,0 & 10,4 & 10,1 & 10,6 & 10,5 & 10,8 & & \\
\hline
\end{tabular}


Таблица 4. Распространенность псориаза, 2009-2016 гг. (на 1000 взрослого населения)

Table 4. Prevalence of psoriasis in 2009-2016 (per 1,000 adult population)

\begin{tabular}{|c|c|c|c|c|c|c|c|c|c|}
\hline \multicolumn{2}{|c|}{ Регион / год } & 2009 & 2010 & 2011 & 2012 & 2013 & 2014 & 2015 & 2016 \\
\hline \multirow[t]{2}{*}{ Алтай } & абс. & 98 & 90 & 82 & 94 & 98 & 110 & 105 & 103 \\
\hline & $\%$ & 6,7 & 5,5 & 5,4 & 6,3 & 6,7 & 4,8 & 4,6 & 4,7 \\
\hline \multirow[t]{2}{*}{ ЗСЖД } & абс. & 834 & 1027 & 948 & 969 & 942 & 1193 & 1009 & \\
\hline & $\%$ & 3,1 & 3,9 & 3,5 & 3,8 & 3,9 & 4,8 & 4,4 & \\
\hline \multicolumn{2}{|c|}{${ }^{3} \mathrm{CФ0}, \%$} & 2,0 & 2,2 & 2,3 & 2,4 & 2,6 & 2,5 & & \\
\hline \multicolumn{2}{|c|}{${ }^{4} \mathrm{P} \Phi, \%$} & 2,3 & 2,4 & 2,4 & 2,5 & 4,1 & 4,4 & 2,7 & \\
\hline
\end{tabular}

Примечание / Note: $p_{1-2}=0,001243 ; p_{1-3}=0,000666 ; p_{1-4}=0,000311 ; p_{2-3}=0,001166 ; p_{2-4}=0,072844$

Таблица 5. Первичная заболеваемость по классу «Болезни кожи и подкожной клетчатки», 2011-2016 гг. (на 1000 взрослых)

Table 5. Newly-diagnosed cases of skin and subcutaneous tissue diseases in 2011-2016 (per 1,000 adult population)

\begin{tabular}{|c|c|c|c|c|c|c|c|c|}
\hline \multicolumn{2}{|c|}{ Население / год } & 2011 & 2012 & 2013 & 2014 & 2015 & 2016 & $M \pm S D$ \\
\hline \multirow{2}{*}{$\begin{array}{c}\text { Алтайский } \\
\text { регион }\end{array}$} & ${ }^{1}$ (на 1000 раб.) & 58,3 & 48,1 & 42,6 & 32,9 & 32,4 & 39,9 & $42,9 \pm 10,9$ \\
\hline & ${ }^{2}$ (на 1000 взр.) & 41,2 & 41,1 & 40,2 & 30,1 & 18,3 & 18,7 & $31,6 \pm 11,0$ \\
\hline \multirow[t]{2}{*}{ ЗСЖД } & 3 (на 1000 раб.) & 33,8 & 31,3 & 25,6 & 21,7 & 19,7 & 19,3 & $25,2 \pm 6,1$ \\
\hline & ${ }^{4}$ (на 1000 взр.) & 31,9 & 28,3 & 20,6 & 19,5 & 17,1 & 16,2 & $22,3 \pm 6,4$ \\
\hline \multirow[t]{2}{*}{ ОАО «РЖД» } & ${ }^{5}$ (на 1000 раб.) & & 37,8 & 37,8 & 36,3 & 32,7 & 28,2 & $34,6 \pm 4,1$ \\
\hline & ${ }^{6}$ (на 1000 взр.) & & 29,0 & 28,0 & 26,6 & 25,6 & 23,6 & $25,6 \pm 2,1$ \\
\hline \multicolumn{2}{|c|}{${ }^{7}$ СФО (на 1000 взр.) } & 35,9 & 35,8 & 36,7 & 37,0 & 32,0 & 31,0 & $35,6 \pm 1,7$ \\
\hline \multicolumn{2}{|c|}{${ }^{8}$ РФ (на 1000 взр.) } & 38,2 & 38,5 & 37,9 & 37,4 & 35,0 & 35,2 & $37,4 \pm 1,4$ \\
\hline
\end{tabular}

Примечание / Note: $p_{1-2}=0,179654 ; p_{1-3}=0,008658 ; p_{1-4}=0,002165 ; p_{1-5}=0,177489 ; p_{1-6}=0,004329 ; p_{1-7}=0,132035 ; p_{1-8}=0,393939 ; p_{2-4}=0,179654 ; p_{2-6}=0,428571 ; p_{2-7}=1,0$; $p_{2-8}=1,0 ; p_{3-4}=0,393939 ; p_{5-6}=0,015873$

Таблица 6. Заболеваемость атопическим дерматитом, 2005-2016 гг. (на 1000 взрослого населения)

Table 6. Incidence of atopic dermatitis in 2005-2016 (per 1,000 adult population)

\begin{tabular}{|c|c|c|c|c|c|c|c|c|c|c|c|c|c|}
\hline \multicolumn{2}{|c|}{ Регион/год } & 2005 & 2006 & 2007 & 2008 & 2009 & 2010 & 2011 & 2012 & 2013 & 2014 & 2015 & 2016 \\
\hline \multirow{2}{*}{ 'Алтай } & абс. & 1 & 1 & - & 2 & 2 & - & 2 & 1 & - & 9 & 5 & - \\
\hline & $\%$ & 0,04 & 0,04 & 0 & 0,1 & 0,11 & 0 & 0,13 & 0,07 & 0 & 0,4 & 0,2 & 0 \\
\hline \multirow{2}{*}{ 23СЖД } & абс. & 357 & 30 & 418 & 353 & 340 & 684 & 382 & 308 & 282 & 138 & 80 & \\
\hline & $\%$ & 1,0 & 0,1 & 1,3 & 1,3 & 1,3 & 1,0 & 1,0 & 1,2 & 1,2 & 0,6 & 0,3 & \\
\hline \multicolumn{2}{|c|}{${ }^{3} \mathrm{C} Ф 0, \%$} & 1,1 & 1,1 & 1,14 & 1,5 & 1,43 & 1,01 & 1,04 & 1,01 & 0,97 & 0,96 & & \\
\hline \multicolumn{2}{|c|}{${ }^{4} \mathrm{P} Ф, \%$} & 0,96 & 0,97 & 0,95 & 0,96 & 0,2 & 0,88 & 0,78 & 0,76 & 0,69 & 0,66 & & \\
\hline
\end{tabular}

Примечание / Note: $p_{1-3}=0,000006 ; p_{1-4}=0,000011 ; p_{2-3}=0,863267 ; p_{2-4}=0,061001$

с 2011 по 2016 г. заболеваемость дерматозами работников основной деятельности снизилась на 31,6 \%. Наибольший уровень впервые в жизни выявленных болезней кожи и подкожной клетчатки у работников отделения - 58,3 на 1000 работающих - был достигнут в 2011 г., а наименьший - 32,4 на 1000 работающих в 2015 г. В среднем incidence за анализируемый период составила 42,9 \pm 10,9 на 1000 работающих. Это самый высокий уровень среди анализируемых групп.

По результатам анализа заболеваемости атопическим дерматитом среди работников ЗСЖД и СФО выявлено, что самые высокие показатели наблюдались среди жителей СФО $(1,1 \pm 0,2)$ и ЗСЖД $(0,9 \pm 0,4)$ на 1000 соответствующего населения (табл. 6). Самый высокий уровень заболеваемости - 0,4 на 1000 работников Алтайского отделения, достигнутый в 2014 г., достоверно ниже цифр СФО и РФ $(p=0,000006$ и $p=$ 0,000011) соответственно. В 2007, 2010, 20132016 гг. новых случаев атопического дерматита у работников Алтайского отделения зарегистрировано не было.

В 2016 г. на Алтайском отделении дороги было выявлено 193 новых случая контактного дерматита (табл. 7). Это соответствует интенсивному показателю 8,9 на 1000 соответствующего населения. Средний показатель за одиннадцатилетний период составил 13,0 \pm 3,4 на 1000 работающих. Заболеваемость контактным дерматитом среди работников алтайского региона выше дорожных циярр $(p=0,000099)-7,3 \pm 1,8$ на 1000 работающих - 
Таблица 7. Заболеваемость контактным дерматитом, 2005-2016 гг. (на 1000 взрослого населения)

Table 7. Incidence of contact dermatitis in 2005-2016 (per 1,000 adult population)

\begin{tabular}{|c|c|c|c|c|c|c|c|c|c|c|c|c|c|}
\hline \multicolumn{2}{|c|}{ Регион/год } & 2005 & 2006 & 2007 & 2008 & 2009 & 2010 & 2011 & 2012 & 2013 & 2014 & 2015 & 2016 \\
\hline \multirow{2}{*}{${ }^{1}$ Алтай } & абс. & 184 & 230 & 289 & 326 & 302 & 295 & 229 & 223 & 184 & 192 & 195 & 193 \\
\hline & $\%$ & 12,6 & 10,1 & 13,3 & 16,4 & 17,0 & 18,1 & 15,2 & 14,96 & 12,6 & 8,4 & 8,6 & 8,9 \\
\hline \multirow{2}{*}{ 23СЖД } & абс. & 2876 & 2730 & 3227 & 2822 & 2020 & 1794 & 1614 & 1552 & 1373 & 1213 & 1297 & \\
\hline & $\%$ & 8,2 & 8,3 & 10,4 & 10,2 & 7,6 & 6,8 & 6,0 & 6,2 & 5,7 & 5,3 & 5,6 & \\
\hline \multicolumn{2}{|c|}{${ }^{3} \mathrm{CФО,} \mathrm{\%}$} & 7,0 & 8,5 & 9,0 & 8,9 & 7,5 & 8,6 & 9,6 & 10,4 & 8,4 & 8,5 & & \\
\hline \multicolumn{2}{|c|}{${ }^{4}$ РФ, \%० } & 7,8 & 9,3 & 9,6 & 9,63 & 8,5 & 9,0 & 10,3 & 10,9 & 9,1 & & & \\
\hline
\end{tabular}

Примечание / Note: $p_{1-2}=0,000099 ; p_{1-3}=0,002648 ; p_{1-4}=0,033865 ; p_{2-3}=0,029480 ; p_{2-4}=0,000006$

Таблица 8. Заболеваемость псориазом, 2004-2015 гг. (на 1000 взрослого населения)

Table 8. Incidence of psoriasis in 2004-2015 (per 1,000 adult population)

\begin{tabular}{|c|c|c|c|c|c|c|c|c|c|}
\hline \multicolumn{2}{|c|}{ Регион/ год } & 2009 & 2010 & 2011 & 2012 & 2013 & 2014 & 2015 & 2016 \\
\hline \multirow{2}{*}{ Алтай } & абс. & 7 & 6 & 7 & 5 & 12 & 21 & 19 & 9 \\
\hline & $\%$ & 0,4 & 0,37 & 0,47 & 0,34 & 0,82 & 0,92 & 0,84 & 0,4 \\
\hline \multirow{2}{*}{ ²ЗЖЖД } & абс. & 151 & 172 & 142 & 174 & 154 & 327 & 103 & \\
\hline & $\%$ & 0,58 & 0,67 & 0,54 & 0,68 & 0,6 & 1,3 & 0,5 & \\
\hline \multicolumn{2}{|c|}{${ }^{3} \mathrm{CФ0,} \mathrm{\%}$} & 0,65 & 0,68 & 0,77 & 0,77 & 0,86 & 0,82 & & \\
\hline \multicolumn{2}{|c|}{${ }^{4} \mathrm{P} Ф, \%$} & 0,76 & 0,75 & 0,75 & 0,74 & 0,72 & 0,71 & & \\
\hline
\end{tabular}

Примечание / Note: $p_{1-3}=0,282384 ; p_{1-4}=0,490842 ; p_{2-3}=0,073427 ; p_{2-4}=0,034965$

и территориальных СФО - 8,6 $\pm 0,96$ ( $p=0,002648)$ и РФ - 9,5 $\pm 0,9(p=0,033865)$ на 1000 взрослого населения соответственно. За период с 2005 по 2016 г. заболеваемость контактным дерматитом у работников алтайского региона регрессировала на 29,4 \% с 12,6 на 1000 работающих до 8,9 на 1000 работающих.

Заболеваемость псориазом по Алтайскому отделению дороги за период с 2009 по 2016 г. самая низкая из анализируемых групп - 0,57 \pm 0,3 на 1000 работающих (табл. 8). Вариабельность признака была высокой 0,4 от 0,34 в 2012 г. до 0,92 в 2014 г. на 1000 соответствующего населения. Достоверных различий в заболеваемости работников региона и взрослого территориального населения СФО - 0,76 $\pm 0,08$ на 1000 взрослых $(p=0,282384)$ и РФ - 0,74 $\pm 0,02$ на 1000 взрослого населения $(p=0,490842)$ - выявлено не было. Среднедорожный показатель зарегистрированных больных с впервые в жизни установленным псориазом 0,7 \pm 0,3 на 1000 работающих выше отделенческого, но достоверно ниже, чем по федеральному округу и в среднем по РФ ( $p=0,034965)$.

Согласно трудовому договору и социальной политике, проводимой в ОАО «РЖД», ведется большая работа по сохранению здоровья работников. Профилактика дерматозов складывается из гигиенически ориентированных технологических мероприятий, коллективных и индивидуальных мер защиты рабочих, лечебно-профрилактических мероприятий.

Все работники алтайского региона в полном объеме обеспечены спецодеждой, средствами индивидуальной и коллективной защиты. На работах, связанных с трудно смываемыми загрязнениями, работникам выдаются очищающие, защитные, регенерирующие и восстанавливающие средства.
В целях оздоровления условий труда, снижения заболеваемости работников железных дорог организованы и работают инженерно-врачебные бригады.

Для раннего выявления дерматозов и проведения мер по их профилактике среди работников железнодорожного транспорта на базе поликлиник НУЗ ОКБ на ст. Барнаул проводятся предварительные и периодические осмотры по приказу МЗ и СР № 302-н, МЗ № 796.

Диспансерным наблюдением охвачены 100 \% нуждающихся, что составило 27,5 на 1000 работающих ОАО «РЖД». Эффрективность диспансеризации среди работников ОАО «РЖД» составила 97,1\%. Хорошие показатели диспансеризации свидетельствуют об активной работе врачей по своевременному выявлению, взятию на «Д» учет и ведению диспансерных больных.

В НУЗ ОКБ на ст. Барнаул ведут постоянную работу школы здоровья: школа больных псориазом, школа «Атопика».

Всем работникам компании доступно санаторнокурортное лечение в санаториях и профилакториях ОАО «РЖД». В реабилитационных центрах работников локомотивных бригад успешно проводится коррекция вегетативных, психоэмоциональных реакций, физиолечение дерматозов.

\section{Заключение}

Условия труда работников железнодорожного транспорта влияют на заболеваемость и распространенность дерматозов. Prevalence заболеваниями кожи и подкожной клетчатки у работников основной деятельности алтайского региона и ЗСЖД, как и по сети дорог, выше, чем у всего взрослого населения, прикрепленного к НУЗ ОКБ ст. Барнаул, жителей СФО и РФ. 
В структуре заболеваемости по классу болезни кожи и подкожной клетчатки у работников компании доминируют аллегодерматозы за счет контактного дерматита. Выявляемость данного дерматоза по алтайскому региону выше, чем по дороге и территории.

Так как тяжелые, часто обостряющиеся, хронические заболевания кожи являются противопоказанием для профессий, обеспечивающих движение поездов, то заболеваемость атопическим дерматитом и псориазом у работников алтайского региона ниже, чем у работников и территориального населения СФО и РФ. Негативное воздействие производственных факторов отразилось на накопленной заболеваемости псориазом у работников алтайского региона. Этот показатель выше распространенности псориаза по сравнению со среднедорожными и территориальными показателями СФО и РФ.
В заключение можно сделать вывод, что в некоторых случаях заболеваемость дерматозами бывает связана с профессиональной деятельностью пациентов. Но планомерно проводимая профилактическая работа, применение современных методов лечения, высокая доступность дерматовенерологической помощи привела к снижению распространенности и заболеваемости болезнями кожи и подкожной клетчатки у работников алтайского региона Западно-Сибирской железной дороги.

Данный положительный опыт «РЖД Медицины» может быть использован в других отраслях промышленности и сельского хозяйства для продления жизненного и профессионального долголетия, улучшения качества жизни населения, работающего в условиях воздействия неблагоприятных фракторов производственной среды.

\section{Литература/References}

1. Кубанова А. А., Кубанов А. А., Мелехина Л. Е. Результаты деятельности медицинских организаций дерматовенерологического профиля, достигнутые в 2016 г. Вестник дерматологии и венерологии. 2017;(4):1227. [Kubanova A. A., Kubanov A. A., Melekhina L. E., Bogdanova E. V. Results of work of dermatovenereologic healthcare organizations in 2016. Vestnik Dermatologii i Venerologii. 2017;(4):12-27. (In Russ.)].

2. Деятельность негосударственных учреждений здравоохранения ОАО «РЖД» в 2016 году. Показатели состояния здоровья работников ОАО «РЖДД, членов их семей, пенсионеров железнодорожного транспорта. Сборник статистических материалов. М.: Департамент здравоохранения ОАО «РЖД», 2016. 263 с. [Activity of the JSC Russian Railways nongovernmental healthcare institutions in 2016. Indicators of the health status of JSC "Russian Railways" employees, members of their families and pensioners. Collection of statistical materials. Moscow: Health Department of JSC "Russian Railways", 2016. 263 p. (In Russ.)].
3. Основные показатели здоровья населения и здравоохранения Сибирского федерального округа в 2016 году. Сборник статистических и аналитических материалов. Выпуск 16. Под редакцией О.В. Стрельченко. Новосибирск: 000 «Сибирское университетское издательство», 2017. 258 c. http://www.somc-nsk.ru [Main indicators of public health and healthcare in the Siberian Federal District in 2016. Collection of statistical and analytical materials. Issue 16. Edited by 0. V. Strelchenko. Novosibirsk: LLC "Siberian University Press", Russia, 2017. 258 p. http://www.somc-nsk.ru (In Russ.)].

4. Ресурсы и деятельность медицинских организаций здравоохранения. III часть. Заболеваемость взрослого населения России в 2015 году. Сборник Министерства здравоохранения Российской Федерации. М., 2016. C. 117-121. http://old.rosminzdrav.ru [Resources and activity of healthcare organizations. Part III. Morbidity in the adult population in Russia in 2015. Collection of the RF Ministry of Healthcare. Moscow, 2016. Pp. 117-121. http://old.rosminzdrav.ru (In Russ.)].

\section{Информация об авторе}

Ольга Анатольевна Карпова - к.м.Н., врач-дерматовенеролог Отделенческой клинической больницы на станции Барнаул ОАО «Российские железные дороги»; старший научный сотрудник института гигиены труда и промышленной экологии Алтайского государственного медицинского университета Министерства здравоохранения Российской Федерации; главный внештатный специалист по дерматовенерологии Западно-Сибирской дирекции здравоохранения ОАО «Российские железные дороги»; e-mail: 0.a.karpova2409@yandex.ru

\section{Information about the author}

Ol'ga A. Karpova - Cand. Sci. (Medicine), Dermatologist, Departmental Hospital at the Station of Barnaul JSC "Russian Railways"; Senior Researcher, Institute of Occupational Medicine and Industrial Ecology, Altai State Medical University; Chief Part-time Specialist in Dermatology and Venereology, West Siberian Health Directorate of JSC "Russian Railways"; e-mail: oakarpova2409@yandex.ru 